\title{
EFFECT OF SOWING DATES AND IRRIGATION TREATMENTS ON GROWTH AND YIELD OF SOME FABA BEAN CULTIVARS
}

\author{
Attia, A. N. E. ; A. M. A.Salama ${ }^{1}$; Ola A. M. El-Galaly ${ }^{2}$ and \\ Marwa K. A. Mohamed ${ }^{2}$ \\ 1- Agronomy Department, Faculty of Agriculture, Mansoura University, \\ Egypt. \\ 2- Food Legumes Research Department, Field Crops Research Institute, \\ Agricultural Research Center, Giza, Egypt.
}

\begin{abstract}
The present investigation was carried out at the Experimental Farm of Sakha Agricultural Research Station, Agricultural Research Center (ARC), Egypt, during two successive seasons $2011 / 2012$ and $2012 / 2013$ to study the effect of sowing date ( $1^{\text {st }}$ October, $1^{\text {st }}$ November and $1^{\text {st }}$ December) and irrigation treatments ( $I_{1}$ - Sowing irrigation plus one irrigation after 30 days from sowing "DFS", $I_{2}$ - Sowing irrigation plus two irrigations after 30 and $90 \mathrm{DFS}$ and $\mathrm{I}_{3}$ - Sowing irrigation plus three irrigations after 30, 90 and 120 DFS) on the performance of some faba bean cultivars (Sakha 1, Sakha 4 and Nubaria 2), as well as, their interaction on growth, seed yield and its attributes. Each sowing date was performed in separate experiment. Every experiment of sowing dates was carried out in split-plot design with three replications. The main plots were assigned to irrigation treatments and sub-plots were assigned to field bean cultivars. The main results could be summarized as follows:

1-Maximum values of growth characters, plant height, number of branches and biological yield/fed were recorded from early sowing date ( $1^{\text {st }}$ October). However, the highest numbers seed yield and its components were obtained from intermediate sowing date ( $1^{\text {st }}$ November).

2-Giving plants sowing irrigation plus two irrigations after 30 and 90 DFS resulted in the highest values of seed yield and its components in both seasons. While, giving plants sowing irrigation plus three irrigations after 30, 90 and 120 DFS recorded the tallest plants and greatest number of branches and biological yield/fed in both seasons.

3-Nubaria 2 cultivar was superior to the other two studied cultivars (Sakha 1 and Sakha 4) in growth characters during both seasons. While, Sakha 4 cultivar exceeded the two other cultivars (Sakha 1 and Nubaria 2) in seed yield and its attributes in both seasons.

It can be recommended that sowing faba bean Sakha 4 cultivar on $1^{\text {st }}$ November and giving plants sowing irrigation plus two irrigations after 30 and 90 DFS to improve faba bean productivity under the environmental conditions of Sakha district, Kafr El-Sheikh Governorate.
\end{abstract}

\section{INTRODUCTION}

Faba bean (Vicia faba L.) is the most important food legume crop in Egypt. It is very important as a source of plant protein and can be used as a vegetable, either green or dried, fresh or canned. It also used as fodder and forage crop for animals and for increasing available nitrogen in the biosphere. The total cultivated area in 2012/2013 season reached about 0.2 million 
feddan and the total production exceeded 269400 ton seeds with an average of $8.98 \mathrm{ardab} / \mathrm{fed}$ (FAO, 2014). There is need to improve productivity and total production to meet the increasing demand for faba bean in Egypt. This could be achieved through enhancing crop breeding and agronomic practices such as sowing dates, irrigation treatments and most promising cultivars as major factors determining faba bean yield and its components as well as seed quality.

Sowing dates refer to the effect of all environmental conditions on large scale on growth and yield of faba bean crop, which differ widely from region to another as reported by many scientists. Moreover, sowing dates is an important factor which significantly affects the timing and duration of the vegetative and reproductive stages as well as yield and its components and seed quality (Refay, 2001 and Turk and Tawaha, 2002). Since, environmental factors such as temperature and light differ with varying sowing dates. Whereas, early date of sowing (late October and early November) resulted significant increase in vegetative growth and production more pods per plant, consequently increased yield and quality of seed (Hussein et al., 2002 ; Mohamed, 2003 ; Oweis et al.,2005 ; Attia et al., 2009 ; EL-Metwally et al., 2013 and Abido and Seadh, 2014). However, each delay in sowing date over mid November resulted in steadily reduction in growth and yield (Abuldahab et al., 2002 ; Mohamed, 2003 and Grenz et al., 2005). So, it is very important to determinate date of sowing for faba bean that achieving the optimum limits for these factors in order to get best yield and quality.

Drought and its consequent stress are one of the important factors which restrict agriculture production in Egypt. Therefore, recognition and utilization crops tolerant to drought and the special crops improvement methods make it possible to use semi arid region. The faba bean crop requires adequate water in all stages of its physiological development to attain optimum productivity. But, there are critical points in its growth stages where lack of soil moisture greatly impacts seed yield. Mohamed et al. (1999) found that seed yield decreased by $52 \%$ and $15.5 \%$ with one and two irrigation, respectively as compared to three irrigations. This reduction in yield may be due to lower number of branches, pods, seeds per plant, pod weight, 100 -seed weight. Hasanein (2000) showed that giving faba bean plants two irrigations (at 60 and 90 days after sowing) or three irrigations (at 60, 90 and 120 days after sowing) recorded the highest seed yield. El-Galfy (2005) revealed that the yield and its components of faba bean (plant height, number of branches/plant, number of seeds/plant, 100-seed weight and seed yield/fed) significantly decreased as the number of irrigations decreased.

Chosen the high yielding cultivars is very important to raise crop productivity and quality. Whereas, faba bean cultivars were significantly different in number of pods and seeds/plant, seed yield per plant and per unit area as well as seed quality (Metwally et al., 2000 ; Abou-Taleb, 2002 and Annicchiarico, 2005 ; Attia et al., 2009 ; Mulualem et al., 2012 and Abido and Seadh, 2014). Therefore, this study is aiming to evaluate the faba bean cultivars for focusing light on the most promising cultivars that can be used on a large scale at studying area. 
Thus, the aim of this investigation was to study the effect of sowing date and irrigation treatments on the performance of some faba bean cultivars to obtain the best seed yield and its components as well as seed quality under the environmental conditions of Sakha district, Kafr El-Sheikh Governorate.

\section{MATERIALS AND METHODS}

Two field experiments were carried out at the Experimental Farm of Sakha Agricultural Research Station, Agricultural Research Center (ARC), Egypt, during two successive seasons 2011/2012 and 2012/2013. The main objectives of this work was to study the effect of sowing date and irrigation treatments on the performance of some faba bean cultivars, as well as, their interaction on growth, seed yield and its components and seed quality.

Each sowing date $\left(1^{\text {st }}\right.$ October "early date", $1^{\text {st }}$ November "intermediate date" and $1^{\text {st }}$ December "late date") was performed in separate experiment. Every experiment of sowing dates was carried out in split-plot design with three replications. The main plots were assigned to three irrigation treatments as follows; $I_{1}$ - Sowing irrigation plus one irrigation after 30 days from sowing (DFS), $I_{2}$ - Sowing irrigation plus two irrigations after 30 and 90 DFS and $I_{3-}$ Sowing irrigation plus three irrigations after 30,90 and 120 DFS. To avoid the effect of lateral movement of irrigation water, the main plots were isolated by levees $1.5 \mathrm{~m}$ wide. The sub-plots were assigned to the three field bean cultivars, i.e. Sakha 1, Sakha 4 and Nubaria 2. The studied field bean cultivars were obtained from Food Legumes Research Department, Field Crops Research Institute, Agricultural Research Center, Giza, Egypt. Origins and pedigree of studied faba bean cultivars are presented in Table 1.

Table 1: Origin, pedigree and some features of three faba bean cultivars.

\begin{tabular}{|c|c|c|}
\hline Cultivar & Origin & Pedigree \\
\hline Sakha 1 & FCRI $^{*}$ & Giza $716 \times 620 / 283 / 85$ \\
\hline Nubaria 2 & FCRI & ILB1550 xRadiation2095/76 \\
\hline Sakha 4 & FCRI & Rena Blanka x 461/845/83 \\
\hline
\end{tabular}

${ }^{*}$ FCRI= Field Crops Research Institute, Giza, Egypt.

The experimental soil was clay in texture with $\mathrm{EC}$ of $2.18-1.09 \mathrm{ds} / \mathrm{m}, \mathrm{pH}$ of 7.98-7.86, organic matter of $1.03-1.19 \%$ and available nitrogen of $24.0-$ $22.8 \mathrm{ppm}$ in the two seasons Each experimental basic unit (sub - plot) included five ridges, each of $60 \mathrm{~cm}$ width and $4.0 \mathrm{~m}$ long, resulted an area of $12.0 \mathrm{~m}^{2}$. The preceding summer crop was rice (Oryza sativa L.) in both seasons.

Calcium superphosphate $\left(15.5 \% \mathrm{P}_{2} \mathrm{O}_{5}\right)$ was applied during soil preparation at the rate of $100 \mathrm{~kg} / \mathrm{fed}$. Sowing time was carried out at three dates as mentioned before on both sides of ridges at $25 \mathrm{~cm}$ between hills and $60 \mathrm{~cm}$ between ridges, which expressed 112000 plants/fed. After full germination plant densities were adjusted by replanting the missing hills or 
thinning the over plants at 21 days from planting leaving healthy plant per hill. Hand hoeing was achieved twice every 21 days to control weeds (before time of irrigations). Nitrogen in the form of ammonium nitrate $(33.0 \% \mathrm{~N})$ at the rate of $15 \mathrm{~kg} \mathrm{~N} / \mathrm{fed}$ as starter dose was added before the first irrigation. Potassium sulphate $\left(48 \% \mathrm{~K}_{2} \mathrm{O}\right)$ at the rate of $50 \mathrm{~kg} / \mathrm{fed}$ was applied to soil in two equal portions, before the first and second irrigations. All the other recommended agricultural practices for faba bean production were applied at the proper time.

\section{Studied characters:}

Two samples were taken during the growth period (45 and 75 DFS), where five guarded plants of each sub-plot were chosen at random. The following growth characters was determined:

1- Leaf area index (LAI): It was measured as described by Watson (1958) and then the following equation was used.

$$
\mathrm{LAI}=\frac{\text { Leaf area per plant }\left(\mathrm{cm}^{2}\right)}{\text { Plant ground area }\left(\mathrm{cm}^{2}\right)}
$$

2- Total dry weight of plant (g). To determine total dry weight of plant and leaves, all plant fractions and leaves were air-dried, then oven dried at $70^{\circ} \mathrm{C}$ till constant weight obtained

3- Crop growth rate (CGR) in g/week: It was determined according to Radford (1967), where: $W_{1}$ and $W_{2}$ refer to dry weight of plant at sampling time $T_{1}$ (45 DFS) and $\mathrm{T}_{2}$ (75 DFS), respectively.

$$
C G R=\frac{W_{2}-W_{1}}{T_{2}-T_{1}}
$$

4- Net assimilation rate (NAR) in $\mathrm{g} / \mathrm{cm}^{2} /$ week: It was determined according to Radford (1967), where: $W_{1}, A_{1}$ and $W_{2}, A_{2}$, respectively refer to dry weight and leaf area of plant at sampling time $T_{1}$ and $T_{2}$, respectively.

$$
N A R=\frac{\left(W_{2}-W_{1}\right)\left(\log _{e} A_{2}-\log _{e} A_{1}\right)}{\left(T_{2}-T_{1}\right)\left(A_{2}-A_{1}\right)}
$$

At harvest time, five guarded plants were taken from each sub-plot to estimate the following characters.

1- Plant height $(\mathrm{cm})$.

2- Number of branches/plant.

3- Number of pods/plant.

4- Number of seeds/plant.

5- 100 - seed weight (g).

6- Seed yield (ardab/fad); whole plants in each sub plot were harvested and left for air drying, then they were threshed and the seeds (which were at 12 $\%$ moisture) were weighted $(\mathrm{kg})$, then converted to ardab per feddan (one $\operatorname{ardab}=155 \mathrm{~kg}$ ). 
7- Biological yield (t/fed); it was calculated according to the following formula:

Biological yield $(\mathrm{t} / \mathrm{fed})=$ seed yield $(\mathrm{t} / \mathrm{fed})+$ straw yield $(\mathrm{t} / \mathrm{fed})$.

All data were statistically analyzed according to the technique of analysis of variance (ANOVA) for the split - plot design to each experiment (soing date), then the combined analysis was achieved between sowing dates as outlined by Gomez and Gomez (1984) using means of "MSTAT-C" computer software package. Least Significant Difference (LSD) method was used to test the differences between treatment means at $5 \%$ level of probability as

\section{RESULTS AND DISCUSSION}

\section{1- Effect of sowing date:}

Sowing dates of faba bean ( $1^{\text {st }}$ October "early date", $1^{\text {st }}$ November "intermediate date" and $1^{\text {st }}$ December "late date") significantly influenced leaf area index (LAI) at 45 DAS, total dry weight of plant at 45 and 75 DAS, crop growth rate (CGR) and net assimilation rate (NAR) at the period of 45-75 DAS, plant height, number of branches, pods and seeds/plant, 100-seed weight, seed and biological yields/fed in both seasons. Maximum values of LAI, total dry weight of plant, CGR and NAR, Plant height, number of branches and biological yield/fed were recorded at the early sowing date $\left(1^{\text {st }}\right.$ October), while the minimum values of these characters were recorded at the late sowing date $\left(1^{\text {st }}\right.$ December $)$ in both seasons. These differences between the sowing dates were probably related to differences in weather conditions. However, the highest numbers of pods and seeds/plant, 100-seed weight and seed yield/fed were obtained as a result of intermediate sowing date of faba bean ( $1^{\text {st }}$ November) in both growing seasons. The increase in leaf area index at early sowing date is caused by an increase in branch numbers or leaves on each branch and in size of successive leaves. Such effect of the early sowing might have been resulted from increased photosynthetic area (leaf area), which resulted in more photosynthetic production and consequently increased dry matter accumulation per unit ground area (CGR) and per unit leaf area (NAR). While, the increases in field bean seed yield and its component characters due to sowing on $1^{\text {st }}$ November might be attributed to the seasonable environmental conditions during this period such as temperature, day length and light intensity which allow rapid germination, establishment, development and ripening, consequently increasing dry matter accumulation, yield components as well as seed yield per unit area. These findings are in agreement with those reported by Mohamed (2003), Grenz et al. (2005), Attia et al. (2009), EL-Metwally et al. (2013) and Abido and Seadh (2014).

\section{2- Effect of irrigation treatments:}

Data in Table 3 show that irrigation treatments i.e. $I_{1}$ - Sowing irrigation plus one irrigation after $30 \mathrm{DFS}, \mathrm{I}_{2^{-}}$Sowing irrigation plus two irrigations after 30 and $90 \mathrm{DFS}$ and $\mathrm{I}_{3}$ - Sowing irrigation plus three irrigations after 30, 90 and 120 DFS had a significant effect on plant height, number of 
branches, pods and seeds/plant, 100-seed weight, seed and biological yields/fed in both seasons. Giving faba bean plants sowing irrigation plus two irrigations after 30 and 90 DFS resulted in the highest values of number of pods and seeds/plant, 100-seed weight and seed yield/fed in both seasons. However, giving faba bean plants sowing irrigation plus three irrigations after 30,90 and 120 DFS recorded the tallest plants and greatest number of branches as well as biological yield/fed in both seasons. On the other hand, the lowest values of all seed yield and its attributes were recorded by application of one irrigation after 30 DFS in addition sowing irrigations in both growing seasons. These increases in seed yield and its components due to reduce water stress and securing sufficient moisture throughout the growing season by giving plants 2 irrigations in addition sowing irrigation may be attributed to enhance photosynthesis process, consequently improvement growth and yields of faba bean. These findings are in good conformity with those reported by Hasanein (2000) who showed that giving faba bean plants two irrigations or three irrigations recorded the highest seed yield, as well as, El-Galfy (2005) who revealed that seed yield and its components of faba bean significantly decreased as the number of irrigations decreased.

\section{3- Performance of faba bean cultivars:}

Faba bean cultivars exhibited a significant difference in LAI at 75 DAS, total dry weight of plant at 45 and 75 DAS, crop growth rate (CGR) and net assimilation rate (NAR) at the period of 45-75 DAS, plant height, number of branches/plant (in the second season only), number of pods/plant (in the first season only), number of seeds/plant, 100-seed weight, seed and biological yields/fed in both seasons as shown from data presented in Tables 2 and 3. Nubaria 2 cultivar was superior to the other two studied cultivars (Sakha 1 and Sakha 4) and resulted in the highest values of LAI at 45 and 75 DAS, total dry weight of plant at 45 and 75 DAS, crop growth rate (CGR) and net assimilation rate (NAR) at the period of 45-75 DAS, whereas the lowest values of these characters were produced from Sakha 4 cultivar in both seasons. While, Sakha 4 cultivar exceeded the two other cultivars (Sakha 1 and Nubaria 2) and produced the highest values of plant height, number of branches, pods and seeds/plant, 100-seed weight and seed yield/fed, whereas the lowest values of these characters were produced from Sakha 1 cultivars in the two growing seasons. However, Sakha 1 cultivar exceeded the two other cultivars (Sakha 4 and Nubaria 2) in biological yield/fed in both seasons. The superiority of Nubaria 2 cultivar in CGR and NAR are interpreted as such genotype had greater photosynthetic area, which resulted in more photosynthesis production and consequently increased accumulated dry matter. These findings might be attributed to the differences in their genetical constitution and genetic factors makeup. Similar results were stated by Annicchiarico (2005), Attia et al. (2009), Mulualem et al. (2012) and Abido and Seadh (2014). 
Table 2: Leaf area index (LAl), total dry weight of plant, crop growth rate (CGR) and net assimilation rate (NAR) after 45 and 75 days from sowing as affected by sowing dates of some faba bean cultivars during 2011/2012 and 2012/2013 seasons.

\begin{tabular}{|c|c|c|c|c|c|c|}
\hline \multirow{3}{*}{ Tharacters } & \multicolumn{2}{|c|}{ Leaf area index (LAI) } & \multicolumn{2}{|c|}{$\begin{array}{c}\text { Total dry weight } \\
\text { (g/plant) }\end{array}$} & \multirow[t]{2}{*}{$\begin{array}{c}\text { CGR } \\
\text { (g/week) }\end{array}$} & \multirow[t]{2}{*}{$\begin{array}{c}\text { NAR } \\
\left(\mathrm{g} / \mathrm{m}^{2} / \text { week }\right)\end{array}$} \\
\hline & \multicolumn{4}{|c|}{ Days from sowing (DFS) } & & \\
\hline & 45 & 75 & 45 & 75 & 45 & 75 \\
\hline \multicolumn{7}{|c|}{$2011 / 2012$} \\
\hline \multicolumn{7}{|l|}{ A-Sowing dates: } \\
\hline $1^{\text {st }}$ October & 2.96 & 7.46 & 19.99 & 46.47 & 162.35 & 41.53 \\
\hline $1^{\text {st }}$ November & 3.12 & 7.67 & 19.99 & 39.33 & 126.31 & 31.88 \\
\hline $1^{\text {st }}$ December & 2.33 & 7.40 & 15.08 & 29.39 & 90.64 & 22.57 \\
\hline F. test & * & NS & * & * & * & * \\
\hline LSD at $5 \%$ & 0.45 & - & 1.84 & 3.21 & 9.65 & 2.23 \\
\hline \multicolumn{7}{|l|}{ B-Cultivars: } \\
\hline Sakha 1 & 2.88 & 6.09 & 17.39 & 37.51 & 121.41 & 31.77 \\
\hline Nubaria 2 & 2.66 & 9.92 & 16.43 & 40.88 & 153.79 & 38.29 \\
\hline Sakha 4 & 2.86 & 6.51 & 21.24 & 36.80 & 104.10 & 25.92 \\
\hline F. test & NS & * & * & * & * & * \\
\hline LSD at $5 \%$ & - & 0.58 & 1.37 & 1.72 & 5.45 & 1.91 \\
\hline \multicolumn{7}{|l|}{ C- Interaction: } \\
\hline$A \times B$ & NS & NS & * & * & * & NS \\
\hline \multicolumn{7}{|c|}{$2012 / 2013$} \\
\hline \multicolumn{7}{|l|}{ A- Sowing dates: } \\
\hline $1^{\text {st }}$ October & 3.11 & 7.46 & 19.45 & 47.23 & 172.83 & 43.03 \\
\hline $1^{\text {st }}$ November & 2.72 & 7.66 & 18.68 & 39.96 & 128.67 & 32.22 \\
\hline $1^{\text {st }}$ December & 2.32 & 7.45 & 14.54 & 30.03 & 97.68 & 24.17 \\
\hline F. test & * & NS & * & * & * & * \\
\hline LSD at $5 \%$ & 0.25 & - & 2.65 & 2.85 & 10.33 & 2.45 \\
\hline \multicolumn{7}{|l|}{ B-Cultivars: } \\
\hline Sakha 1 & 2.68 & 6.01 & 16.08 & 38.20 & 134.34 & 33.50 \\
\hline Nubaria 2 & 2.76 & 9.99 & 15.89 & 41.55 & 154.75 & 38.53 \\
\hline Sakha 4 & 2.69 & 6.55 & 20.70 & 37.47 & 110.09 & 27.40 \\
\hline F. test & NS & * & * & * & * & * \\
\hline LSD at $5 \%$ & - & 0.56 & 1.63 & 1.83 & 6.40 & 1.73 \\
\hline \multicolumn{7}{|l|}{ C- Interaction: } \\
\hline$A \times B$ & NS & NS & NS & * & * & * \\
\hline
\end{tabular}

\section{4- Effect of interactions:}

Regarding the effect of interactions, there are many significant effects of the interactions on the studied characters. We present only the effect of significant interactions on seed yield (Tables 4, 5 and 6).

Seed yield/fed was significantly affected by the interaction between sowing dates and irrigation treatments during 2011/2012 and season. From data listed in Table 4 the highest value of seed yield/fed (18.7 ardab/fed) was obtained as a result of sowing faba bean plants on $1^{\text {st }}$ November and giving plants sowing irrigation plus two irrigations (after 30 and 90 DFS). This treatment followed by sowing faba bean plants on $1^{\text {st }}$ November and giving plants sowing irrigation plus three irrigations (after 30, 90 and 120 DFS). 
Table 3: Plant height, number of branches, pods and seeds/plant, 100 seed weight, seed and biological yields/fed as affected by sowing dates and irrigation treatments of some faba bean cultivars as well as their interactions during 2011/2012 and 2012/2013 seasons.

\begin{tabular}{|c|c|c|c|c|c|c|c|}
\hline Treatments & $\begin{array}{l}\text { Plant } \\
\text { height } \\
\text { (cm) }\end{array}$ & $\begin{array}{c}\text { No. of } \\
\text { branches } \\
\text { /plant }\end{array}$ & $\begin{array}{l}\text { No. of } \\
\text { pods/ } \\
\text { plant }\end{array}$ & $\begin{array}{l}\text { No. of } \\
\text { seeds/ } \\
\text { plant }\end{array}$ & $\begin{array}{c}\text { 100-seed } \\
\text { weight } \\
(\mathrm{g})\end{array}$ & $\begin{array}{c}\text { Seed yield } \\
\text { (ardab/ } \\
\text { fed) }\end{array}$ & $\begin{array}{c}\text { Biologica } \\
\text { I yield } \\
\text { (t/fed) }\end{array}$ \\
\hline \multicolumn{8}{|c|}{ 2011/2012 season } \\
\hline \multicolumn{8}{|l|}{ A- Sowing dates: } \\
\hline $1^{\text {st }}$ October & 175.6 & 1.50 & 8.64 & 25.91 & 69.08 & 11.64 & 2.53 \\
\hline $1^{\text {st }}$ November & 153.0 & 1.35 & 14.14 & 42.43 & 77.06 & 17.14 & 2.43 \\
\hline $1^{\text {st }}$ December & 115.5 & 0.53 & 8.36 & 25.07 & 60.92 & 11.36 & 1.75 \\
\hline F. test & ${ }^{*}$ & ${ }^{*}$ & * & ${ }^{*}$ & * & * & * \\
\hline LSD at $5 \%$ & 2.63 & 0.10 & 0.44 & 1.01 & 0.65 & 0.44 & 0.05 \\
\hline \multicolumn{8}{|c|}{ B- Irrigation treatments: } \\
\hline $\mathrm{I}_{1}$ - One irrigation & 142.3 & 1.11 & 8.09 & 24.22 & 67.73 & 11.09 & 1.97 \\
\hline$I_{2}$ - Two irrigations & 149.2 & 1.20 & 11.64 & 34.93 & 69.46 & 14.64 & 2.37 \\
\hline$I_{3}$-Three irrigations & 152.6 & 1.36 & 11.41 & 34.26 & 69.87 & 14.41 & 2.39 \\
\hline F. test & * & * & * & * & * & * & * \\
\hline LSD at $5 \%$ & 2.52 & 0.13 & 0.61 & 1.68 & 0.42 & 0.61 & 0.09 \\
\hline \multicolumn{8}{|l|}{ C-Cultivars: } \\
\hline Sakha 1 & 144.8 & 1.10 & 9.97 & 29.87 & 69.76 & 12.97 & 2.33 \\
\hline Nubaria 2 & 148.8 & 1.14 & 10.25 & 30.76 & 64.35 & 13.25 & 2.13 \\
\hline Sakha 4 & 150.6 & 1.14 & 10.91 & 34.78 & 72.96 & 13.91 & 2.15 \\
\hline F. test & * & NS & * & * & * & $*$ & * \\
\hline LSD at $5 \%$ & 1.93 & - & 0.63 & 1.49 & 0.39 & 0.63 & 0.06 \\
\hline \multicolumn{8}{|l|}{ Interactions: } \\
\hline$A \times B$ & * & NS & * & * & * & * & NS \\
\hline$A \times C$ & * & * & NS & NS & * & NS & * \\
\hline$B \times C$ & * & NS & * & * & NS & * & * \\
\hline$A \times B \times C$ & * & NS & * & * & NS & * & * \\
\hline \multicolumn{8}{|c|}{ 2012/2013 season } \\
\hline \multicolumn{8}{|l|}{ A- Sowing dates: } \\
\hline $1^{\text {st }}$ October & 159.9 & 1.63 & 8.66 & 27.02 & 76.44 & 9.48 & 2.26 \\
\hline $1^{\text {st }}$ November & 145.2 & 1.39 & 14.79 & 45.36 & 79.55 & 16.14 & 2.13 \\
\hline $1^{\text {st }}$ December & 92.5 & 0.66 & 7.70 & 23.10 & 68.80 & 10.78 & 1.47 \\
\hline F. test & * & * & * & * & * & * & * \\
\hline LSD at $5 \%$ & 1.87 & 0.16 & 0.35 & 1.79 & 0.51 & 0.68 & 0.07 \\
\hline \multicolumn{8}{|c|}{ B- Irrigation treatments: } \\
\hline$I_{1}$ - One irrigation & 132.0 & 1.23 & 8.87 & 27.59 & 73.68 & 9.69 & 1.69 \\
\hline$I_{2-}$ Two irrigations & 131.1 & 1.15 & 10.95 & 33.37 & 75.10 & 13.32 & 2.09 \\
\hline$I_{3}$-Three irrigations & 134.4 & 1.31 & 11.32 & 34.52 & 76.02 & 13.39 & 2.19 \\
\hline F. test & * & * & * & * & * & * & * \\
\hline LSD at $5 \%$ & 2.29 & 0.11 & 0.32 & 1.12 & 0.33 & 0.88 & 0.07 \\
\hline \multicolumn{8}{|l|}{ C-Cultivars: } \\
\hline Sakha 1 & 128.2 & 1.36 & 10.20 & 31.64 & 72.00 & 11.14 & 2.04 \\
\hline Nubaria 2 & 133.7 & 1.12 & 10.35 & 31.43 & 74.73 & 12.59 & 1.85 \\
\hline Sakha 4 & 135.7 & 1.20 & 10.59 & 35.41 & 78.06 & 12.67 & 1.96 \\
\hline F. test & * & * & NS & * & * & * & * \\
\hline LSD at $5 \%$ & 1.83 & 0.11 & - & 1.81 & 0.36 & 0.81 & 0.06 \\
\hline \multicolumn{8}{|l|}{ Interactions: } \\
\hline$A \times B$ & * & NS & * & * & NS & NS & NS \\
\hline$A \times C$ & * & NS & * & * & * & NS & NS \\
\hline$B \times C$ & * & * & * & * & NS & * & * \\
\hline$A \times B \times C$ & * & NS & * & * & NS & NS & * \\
\hline
\end{tabular}


Table 4: Seed yield (ardab/fed) as affected by the interaction between sowing dates and irrigation treatments during 2011/2012 and season.

\begin{tabular}{|l|c|c|c|}
\hline \multirow{2}{*}{$\begin{array}{l}\text { Irrigation } \\
\text { treatments }\end{array}$} & \multicolumn{3}{|c|}{ Sowing dates } \\
\cline { 2 - 4 } & $\mathbf{1}^{\text {st }}$ October & $\mathbf{1}^{\text {st }}$ November & $\mathbf{1}^{\text {st }}$ December \\
\hline $\mathrm{l}_{1}$ - One irrigation & 9.0 & 14.0 & 10.2 \\
\hline $\mathrm{l}_{2}$ - Two irrigations & 13.1 & 18.7 & 12.1 \\
\hline $\mathrm{I}_{3}$-Three irrigations & 12.8 & 18.7 & 11.8 \\
\hline F. test & \multicolumn{3}{|c|}{} \\
\hline LSD at 5\% & ${ }^{*}$ & 1.1 \\
\hline
\end{tabular}

Table 5: Seed yield (ardab/fed) as affected by the interaction between irrigation treatments and cultivars during 2011/2012 and 2012/2013 seasons.

\begin{tabular}{|c|c|c|c|c|c|c|}
\hline \multirow{3}{*}{ Cultivars } & \multicolumn{6}{|c|}{ Irrigation treatments } \\
\hline & \multicolumn{3}{|c|}{ 2011-2012 } & \multicolumn{3}{|c|}{ 2012-2013 } \\
\hline & $\begin{array}{c}\mathrm{I}_{1}-\text { One } \\
\text { irrigation }\end{array}$ & $\begin{array}{c}\mathrm{I}_{2}-\mathrm{Two} \\
\text { irrigations }\end{array}$ & $\begin{array}{c}I_{3} \text {-Three } \\
\text { irrigations }\end{array}$ & $\begin{array}{c}\mathrm{I}_{1} \text { - One } \\
\text { irrigation }\end{array}$ & \begin{tabular}{|c|}
$\mathrm{I}_{2}-\mathrm{Two}$ \\
irrigations
\end{tabular} & $\begin{array}{c}I_{3} \text {-Three } \\
\text { irrigations }\end{array}$ \\
\hline Sakha 1 & 9.4 & 15.0 & 14.4 & 7.9 & 12.5 & 13.0 \\
\hline Nubaria 2 & 13.4 & 12.9 & 13.5 & 11.9 & 13.1 & 13.1 \\
\hline Sakha 4 & 10.4 & 16.0 & 15.3 & 9.3 & 14.4 & 14.1 \\
\hline \multicolumn{7}{|l|}{ F. test } \\
\hline LSD at $5 \%$ & & 1.1 & & & 1.4 & \\
\hline
\end{tabular}

Table 6: Seed yield (ardab/fed) as affected by the interaction among sowing dates, irrigation treatments and cultivars during 2011/2012 season.

\begin{tabular}{|c|c|c|c|c|}
\hline \multirow{2}{*}{\begin{tabular}{|l} 
Irrigation \\
treatments
\end{tabular}} & \multirow{2}{*}{ Cultivars } & \multicolumn{3}{|c|}{ Sowing dates } \\
\hline & & $1^{\text {st }}$ October & $1^{\text {st }}$ November & $1^{\text {st }}$ December \\
\hline \multirow{3}{*}{$l_{1}$ - One irrigation } & Sakha 1 & & 11.8 & 9.3 \\
\hline & Nubaria 2 & 10.5 & 18.0 & 11.5 \\
\hline & Sak & 9.3 & 12.3 & 9.8 \\
\hline \multirow[b]{2}{*}{$\mathrm{I}_{2}$ - Two irrigations } & & 14.3 & 19.3 & 11.5 \\
\hline & $\begin{array}{l}\text { Nubaria } 2 \\
\text { Sakha } 4\end{array}$ & $\begin{array}{l}11.8 \\
13.3\end{array}$ & $\begin{array}{l}16.0 \\
20.8\end{array}$ & $\begin{array}{l}10.8 \\
14.0\end{array}$ \\
\hline \multirow{2}{*}{$\begin{array}{l}I_{3-T h r e e}^{-} \\
\text {irrigations }\end{array}$} & Sakha 1 & 12.5 & $\begin{array}{l}19.0 \\
173\end{array}$ & 11.8 \\
\hline & $\begin{array}{c}\text { Nubaria } 2 \\
\text { Sakha } 4\end{array}$ & $\begin{array}{l}12.5 \\
13.3\end{array}$ & $\begin{array}{l}17.3 \\
19.8\end{array}$ & $\begin{array}{l}10.8 \\
12.8\end{array}$ \\
\hline \multicolumn{2}{|l|}{$\begin{array}{l}\text { F. test } \\
\text { LSD at } 5 \%\end{array}$} & \multicolumn{3}{|c|}{9} \\
\hline
\end{tabular}

The interaction between irrigation treatments and cultivars significantly affected seed yield per feddan in both seasons. Giving plants of Sakha 4 cultivar sowing irrigation plus two irrigations (after 30 and 90 DFS) produced the highest values of seed yield (16.0 and $14.4 \mathrm{ardab} / \mathrm{fed}$ ) in the first and second seasons, respectively (Table 5 ). This treatment followed by giving plants of Sakha 4 cultivar sowing irrigation plus three irrigations (after 30, 90 and 120 DFS) in both seasons.

The interaction among sowing dates, irrigation treatments and cultivars excreted significant effect on seed yield/fed in the first season. The highest value of seed yield (20.8 ardab/fed) were obtained from sowing faba 
bean plants on $1^{\text {st }}$ November and giving plants of Sakha 4 cultivar sowing irrigation plus two irrigations (after 30 and 90 DFS) as shown from data in Table 6 . This interaction treatment followed by sowing faba bean plants on $1^{\text {st }}$ November and giving plants of Sakha 4 cultivar sowing irrigation plus three irrigations (after 30, 90 and 120 DFS).

\section{REFERENCES}

Abido, W.A.E. and S.E. Seadh (2014). Rate of variations between field bean cultivars due to sowing dates and foliar spraying treatments. Science International, 2(1): 1-12.

Abou-Taleb, S.M. (2002). Morphological variation and dry matter distribution in some faba bean cultivars under different sowing dates. Proc of Recent Technologies in Agriculture, Fac. Agric. Cairo Univ., 28-30 Oct. 2002, Bull. Fac. Agric. Cairo Univ., Egypt, Vol. (IV): 846-874.

Abuldahab, A.A. ; W.A. EL-Murshedy and G.O. Mahmoud (2002). Phenological response of faba bean to climatological effects under different sowing dates and plant distributions. J. Agric. Sci. Mansoura Univ., 27(4): 1989-2003.

Annicchiarico, P. (2005). Pea, faba bean and lupin for autumn and late winter sowing. Informatore Agrario., 61(39): 61-65 (C.F. Computer Search).

Attia, A.N. ; S.E. Seadh ; M.I. EL-Emery and R.M.H. El-Khairy (2009). Effect of planting dates and seed size on productivity and quality of some faba bean cultivars. J. Agric. Sci. Mansoura Univ., 34 (12): 1131111324.

El-Galfy, A.M.K. (2005). Effect of some irrigation treatments on yield, yield components and seed quality characteristics of same faba bean (Vicia faba L.) varieties. Annals of Agric. Sci., Moshtohor, 43(1):51-62.

El-Metwally, I.M. ; T.A. El-Shahawy and M.A. Ahmed (2013). Effect of sowing dates and some broomrape control treatments on faba bean growth and yield. J. of Appl. Sci. Res., 9(1): 197-204.

Food and Agriculture Organization (2014). FAO Statistics Division, 2014.

Gomez, K.N. and A.A. Gomez (1984). Statistical procedures for agricultural research. John Wiley and Sons, New York, $2^{\text {nd }}$ ed., 68 p.

Grenz, J.; A.M. Manschadi; F.N. Uygur and J. Sauerborn (2005): Effects of environment and sowing date on assimilate competition between faba bean (Vicia faba) and the parasitic weed Orobanche crenata. Field Crops Res., 93: 300-313.

Hasanein, M.S. (2000). Response of some faba bean varieties to water supply. Annals of Agric. Sci., Moshtohor, 38(3):1383-1398.

Hussein, A.H.A. ; M.A. El-Deeb and K.H. El-Yamani (2002). Response of new faba bean genotypes to different sowing dates and plant densities in the newly reclaimed land in upper Egypt. National Ann. Coordination Meeting, ICARDA/EC, Cairo, 22-23 September I: 70-74. 
Hussein, A.H.A. ; M.A. El-Deeb and K.H. El-Yamani (2002). Response of new faba bean genotypes to different sowing dates and plant densities in the newly reclaimed land in upper Egypt. National Ann. Coordination Meeting, ICARDA/EC, Cairo, 22-23 September I: 70-74.

Mohamed, A.A ; E.N. Gendy and S.R. Saleeb (1999). The combined effect of irrigation number and gypsum applications on faba bean (Vicia faba L.) yield and its main components. Annals of Agric. Sci., Moshtohor. 1999; 37(4): 2805-2812.

Mohamed, A.A. (2003). Effect of planting date on growth and yield of some Faba Bean varieties. M.Sc. Thesis in Agron. Fac. of Agric. Cairo Univ., Egypt.

Mulualem, T. ; T. Dessalegn and Y. Dessalegn (2013). Participatory varietal selection of faba bean (Vicia faba L.) for yield and yield components in Dabat district, Ethiopia. Wudpecker J. of Agric. Res., 1(7): 270 - 274.

Oweis, T. ; A. Hachum and M. Pala (2005). Faba bean productivity under rainfed and supplemental irrigation in northern Syria. Agric. Water Management, 73: 57-72.

Radford, P.J. (1967). Growth analysis formulae, their use and abuse. Crop Sci., 7: 171-175.

Refay, Y.A. (2001). Effect of planting dates and plant density on two Faba Bean lines grown under the central region conditions of Saudi Arabia. Arab. Univ. J. of Agric. Sci., 9 (1): 79-93.

Snedecor, G.W. and W.G. Cochran (1980). "Statistical Methods" $7^{\text {th }}$ Ed. The lowa State Univ. Press, lowa, USA.

Turk, M.A. and A.R.M. Tawaha (2002). Effect of dates of sowing and seed size on yield and yield components of local faba bean under semi-arid conditions. Legume Res., 25(4): 301-302.

Watson, D.J. (1958). The dependence of net assimilation rate on leaf area index. Ann. Bot. Lond. N.S., 22:37-54. 
Attia, A. N. E. et al.

تأثير مواعيد الزراعة ومعاملات الري على المحصول وبعض صفات النمو لبعض أصناف الفول البلدي البري

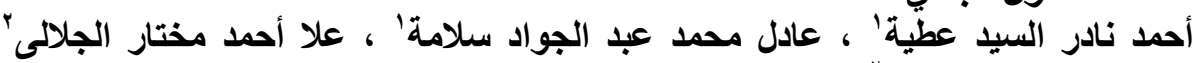

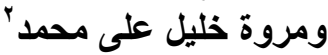

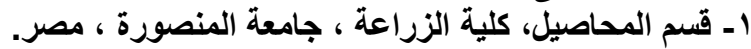

r - قسم بحوث المحاصيل البقولية ، معهد بحوث المحاصيل الحقلية ، مركز البحوث الزراعية ،

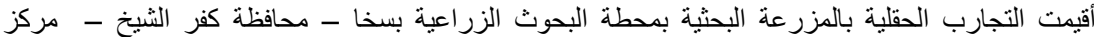

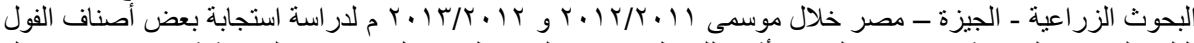

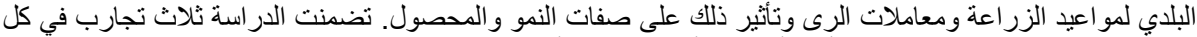

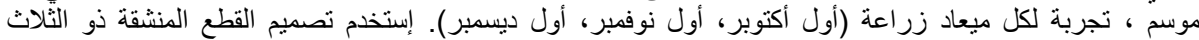

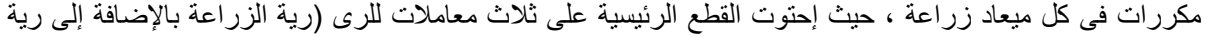

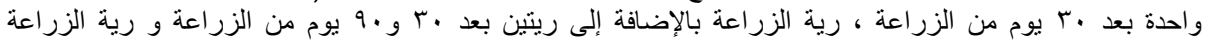

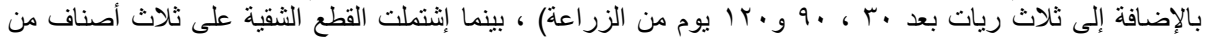

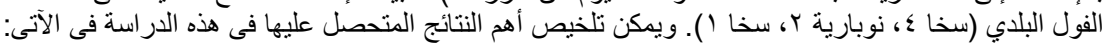

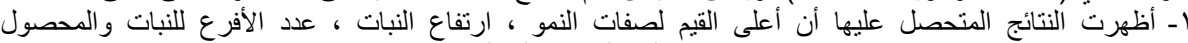

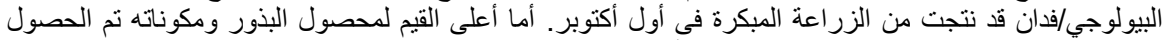

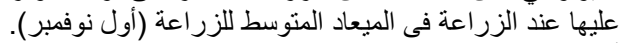

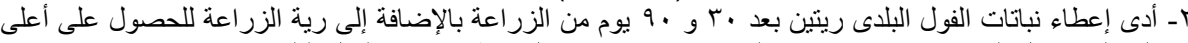

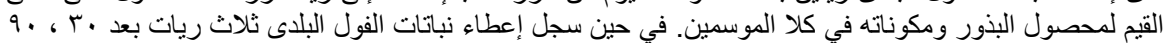
و ـr ا يوم من الزراعة بالإضافة إلى رية الزراعة أطول النباتات و أكبر عدد من الفروع و المحصول البيولوجي/فدان

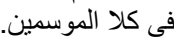

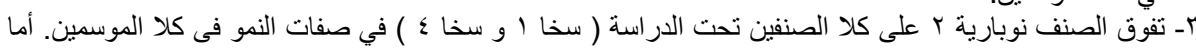

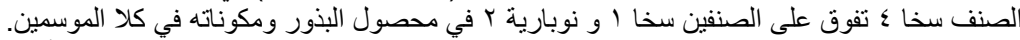

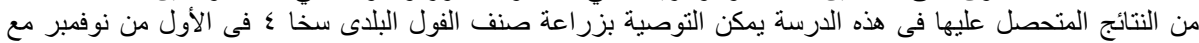

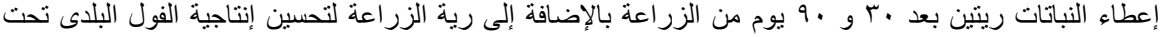
الظروف البيئية لكنطقة سخا ، محافظة كفر الثيخ.

كلية الزراعة - جامعة المنصورة كلية الزراعة - جامعة كفر الشيخ
قام بتحكيم البحث

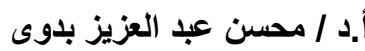

أ.د / صبحى غريب رزق سرور 